\title{
Use of Ozone for Inactivation of Bacteria and Viruses in Cryostats
}

Ingo Maier ${ }^{\star}$ and Timothy Chu

${ }^{1}$ Ecoscope, Microbiological Laboratory, Amtzell, Germany

${ }^{2}$ Sakura Finetek USA, Inc., Pathology Lab Instrument Manusfacturer, California, USA

*Corresponding author: Maier I, Ecoscope, Microbiology Lab, Hochgratweg 12, 88279 Amtzell, Germany, Tel: +49 7520 953660; E-mail: admin@ecoscope.de

Received date: July 11, 2016; Accepted date: August 17, 2016; Published date: August 27, 2016

Copyright: (C) 2016, Maier I, et al. This is an open-access article distributed under the terms of the Creative Commons Attribution License, which permits unrestricted use, distribution, and reproduction in any medium, provided the original author and source are credited.

\begin{abstract}
The biocidal efficacy of ozone has been investigated in cryostats at $-20^{\circ} \mathrm{C}$ and $+30^{\circ} \mathrm{C}$ and $30-120$ min exposure time. Stainless steel coupons were inoculated with $50 \mu \mathrm{l}$ bacterial or viral test suspension. The tests were performed using Staphylococcus aureus and Mycobacterium terrae as test bacteria and Polyoma virus (Simian virus 40, SV 40). The inoculated coupons were exposed to a combination of ozone and UV generated by UV lamps in the cryostats. To measure the level of disinfection achieved, the number of surviving bacteria recovered from the coupons and, respectively, the virus infectivity titer was determined. Reduction factors were calculated by dividing the initial titer by the titer of recovered viable bacteria or virus.

Bactericidal efficacy at $-20^{\circ} \mathrm{C}$ was demonstrated by inactivation of $\mathrm{S}$. aureus by at least $5 \log 10$ units in an automatic defrost $/ 60 \mathrm{~min}$ ozone cycle in all test positions, which allowed to remove the $+30^{\circ} \mathrm{C} / 120 \mathrm{~min}$ test from the testing panel. In a 30 min treatment, a disinfection rate of $5 \log 10$ units was achieved in some, but not all test positions. Mycobacterium terrae, the substitute for the pathogenic M. tuberculosis, was inactivated by $>5.3 \log 10$ units in all tested locations using a 120 -minute ozone cycle at $+30^{\circ} \mathrm{C}$. The infective virus titer was reduced by at least $5 \log 10$ units in the same ozone cycle on the pressure plate and chuck positions. Apart from this, significant reductions in viable cell and virus numbers have been shown for all disinfection protocols and test positions, thus demonstrating the principle efficacy of a combination of gaseous ozone and UV as a disinfectant in cryostats.
\end{abstract}

Keywords: Cryostat chamber; High-level disinfection; Mycobacterium; Ozone; Staphylococcus; UVC; Polyoma virus

\section{Introduction}

In cryotomy, the risk of transmittance of health-care associated pathogens from tissue samples and surfaces is of particular concern. For optimal staff protection, it is often desirable to reduce the risk of contamination by a simple disinfection routine that can be conveniently applied between sectioning sessions. For this reason, there has been interest in treating cryostat chambers with a fumigant that in a rapid and safe way will inactivate pathogens on all surfaces and even in spaces.

Ozone, as a highly potent oxidant, is able to inactivate a broad range of microorganisms and viruses. The susceptibility of micro-organisms and viruses to ozone has been tested in a large number of investigations but ozone's mode of action against microorganisms is only incompletely understood. Some studies suggest that molecular ozone oxidizes proteins and unsaturated fatty acids in biological membranes, leading to cell lysis or damage of viral envelopes and capsids. Ozone may also disrupt cellular enzyme activity and react with nucleic acids. Hydroxyl radicals from ozone decomposition are also highly reactive, but unspecific oxidants [1-7].

High-level antimicrobial activity of ozone on surfaces or in air has been demonstrated in only few studies. The biocidal efficacy of ozone is determined by a variety of factors, besides concentration and exposure time, including temperature, relative humidity, presence or absence of organic matter, micro-organism type, surface composition and structure, and aggregation. Pathogens may be adsorbed to cryostat surfaces or embedded within tissue debris. It is evident that the complexes that result may be much more resistant to ozone than pathogens in the free state [8].

The aim of the present study was to examine the disinfection efficacy of ozone combined with UV treatment in cryostats, making use of the ability of gaseous ozone to diffuse throughout the space and penetrate into crevices. Four parameters are the major contributors to pathogen inactivation in a cryostat: temperature, ozone concentration, UV irradiance and exposure time. The Gram-positive bacterium Staphylococcus aureus, Mycobacterium terrae and Polyoma virus (Simian virus 40, SV40) have been employed as standard surrogate organisms in carrier tests [9-11]. The experiments were performed at a working temperature of $-20^{\circ} \mathrm{C}$ and, in addition, at $+30^{\circ} \mathrm{C}$ with variable exposure time, using two cryostat models.

\section{Materials and Methods}

\section{Test instruments}

Two cryostats were used in the experiments. A TISSUE TEK $\mathrm{CRYO}^{\circ}$ PLUS cryostat was used for ozone treatment at $-20^{\circ} \mathrm{C}$, and a TISSUE TEK ${ }^{\circ} \mathrm{CRYO}^{\circ}$ FLEX (Sakura Finetek USA, Inc., Torrance, CA) were equipped with new low pressure mercury vapor lamps with quartz glass lamp sleeves as ozone generating systems.

\section{Ozone measurements}

The ozone generating lamps show major emission lines at $254 \mathrm{~nm}$ ("UV-C") and $185 \mathrm{~nm}$ ("VUV"). Absorption of VUV by oxygen molecules in the ambient air leads to photolysis of oxygen molecules 
and formation of ozone by reaction of oxygen atoms with other oxygen molecules. Simultaneously, photolysis of ozone occurs by UV-C absorption, in addition to spontaneous decomposition to oxygen. Thus, a steady state ozone concentration gradient is generated in the cryostat tub during lamp operation [12].

The time course of ozone formation in the cryostats at various positions and with different disinfection schemes has been measured using a 2B Technologies (Boulder, CO, USA) 106-M ozone monitor. The total ozone doses were determined as the sum of single concentration measurements made in $10 \mathrm{sec}$ intervals over complete ozonation cycles. The equilibrium concentration is reached within 20-30 min lamp operation. At the end of the cycle, ozone is rapidly purged from the cryostat tub. The ozone levels were uniform throughout the cryostat tub $( \pm 2 \%)$. In the TISSUE TEK CRYO3 PLUS, the average total doses were $32,100,75,360$ and 180,440 $\mathrm{ppm}^{\star} \mathrm{min}$ in the 30,60 , and $120 \mathrm{~min}$ treatments at $-20^{\circ} \mathrm{C}$, respectively In the TISSUE TEK ${ }^{\circ} \mathrm{CRYO}^{\circ}$ FLEX chamber, the ozone concentration was slightly higher than in the TISSUE TEK ${ }^{\circ} \mathrm{CRYO}^{\circ}$ PLUS after 30 and $60 \mathrm{~min}$ at $-20^{\circ} \mathrm{C}$ and thus a slightly higher disinfection rate can be expected. When the chamber temperature in the TISSUE TEK $\mathrm{CRYO}^{\circ}$ FLEX was raised to $+30^{\circ} \mathrm{C}$, an ozone dose of $78.460 \mathrm{ppm}^{\star} \mathrm{min}$ was reached in a 120 min disinfection cycle.

\section{Test strains}

As a test strain for bactericidal activity, the gram positive bacterium Staphylococcus aureus ATCC 6538 was used. The frozen bacterial stock was suspended in tryptic soy broth (TSB) and incubated at $35 \pm$ $1^{\circ} \mathrm{C}$ for $18-24$ h. $0.1 \mathrm{~mL}$ aliquots of the liquid culture were plated on tryptic soy agar (TSA) and incubated at $35 \pm 1^{\circ} \mathrm{C}$ for $18-24 \mathrm{~h}$. For the test suspension, bacteria were rinsed off a plate with $10 \mathrm{~mL}$ sterile deionized water (SDW), homogenized by vortexing with sterile glass beads and washed twice with SDW by centrifugation $(2.000 \mathrm{~g}, 20 \mathrm{~min}$, $5^{\circ} \mathrm{C}$ ). After the third centrifugation step, the pellet was re-suspended in $3 \mathrm{~mL}$ SDW. The suspension was homogenized by vortexing with sterile glass beads at maximum speed for $3 \mathrm{~min}$ and diluted to 108-109 colony forming units per $\mathrm{mL}(\mathrm{cfu} / \mathrm{mL})$ with SDW. The test suspensions were stored in a fridge and used within $4 \mathrm{~h}$. The tests were performed without adding interfering substances.

Mycobacterium terrae ATCC 15755 was employed for demonstrating tuberculocidal activity $[13,14]$. The bacterial stock was suspended in Middlebrook $7 \mathrm{H} 9$ broth with OADC (MBB) (Merck Chemicals, Darmstadt, Germany) and incubated at $36 \pm 1^{\circ} \mathrm{C}$ for $48 \mathrm{~h}$. $0.1 \mathrm{~mL}$ aliquots of the liquid culture were spread on Middlebrook 7H10 agar with OADC (MBA) (Merck Chemicals, Darmstadt, Germany), sealed in polyethylene bags and incubated at $36 \pm 1{ }^{\circ} \mathrm{C}$ for about 21 days. The bacteria were rinsed off a plate with $10 \mathrm{~mL}$ SDW, homogenized by vortexing with sterile glass beads and washed twice with SDW by centrifugation $\left(2.000 \mathrm{~g}, 20 \mathrm{~min}, 5^{\circ} \mathrm{C}\right)$. Afterward, the pellet was re-suspended in $3 \mathrm{~mL}$ SDW. The suspension was homogenized by vortexing $(3 \mathrm{~min})$ with sterile glass beads at maximum speed and diluted to 108-109 colony forming units per $\mathrm{mL}$ $(\mathrm{cfu} / \mathrm{mL})$ with SDW. The test suspensions were stored in a fridge and used for two experiments on consecutive days. The tests were performed without adding interfering substances.

Polyoma virus (Simian Virus 40, SV40), strain 777 (MikroLab $\mathrm{GmbH}$, Bremen, Germany) was multiplied in African green monkey kidney cells (CV 1 cells) to produce high titers of infectious viruses. The cell culture originated from the European Collection of Authenticated Cell Cultures (ECACC, Salisbury, UK). CV 1 cells were cultivated at $37 \pm 2{ }^{\circ} \mathrm{C}$ with $5 \% \mathrm{CO}_{2}$. Virus suspensions with cell detritus were frozen and thawed two times. The cell detritus was then separated by low speed centrifugation and the supernatant was stored at $\leq-60^{\circ} \mathrm{C}$. Virus suspension were prepared in virus test medium without serum (Dulbecco's modified Eagle's medium, supplemented with L-glutamine and 100 units $/ \mathrm{mL}$ penicillin, $130 \mu \mathrm{g} / \mathrm{mL}$ streptomycin). During inactivation experiments, the virus test suspension was stored in a refrigerator $\left(+4\right.$ to $\left.+7^{\circ} \mathrm{C}\right)$.

\section{Inactivation experiments}

Sterilized stainless steel coupons $(20 \times 1 \mathrm{~mm})$ of the same material as the cryostat tub (SAE grade 304, bead blast with round glass beads mesh 140/170, passivated per AMS2700E type 2 class 2) were each inoculated with $50 \mu \mathrm{L}$ test suspension (Figure 1). The suspensions were evenly spread using fine glass loops. After drying to optical dryness in a laminar flow cabinet, the inoculated coupons were transferred into the cryostat, equilibrated to $-20^{\circ} \mathrm{C}$, and then subjected to the ozone treatment schemes described in Table 1 . The coupons were variably placed in up to five test positions (Figure 2) in triplicate. Ozone treatment for 60 and $120 \mathrm{~min}$ was preceded by a $60 \mathrm{~min}$ defrost period. Ozone was generated throughout the treatment periods. Afterward, it was rapidly purged from the cryostat chamber.

In control experiments, the coupons were removed from the instrument before start of the ozone treatment routine. In Polyoma virus, positive virus inactivation controls with formaldehyde were performed. Interference of possible ozone reaction products with susceptibility of the CV 1 cell line was excluded in additional control experiments.

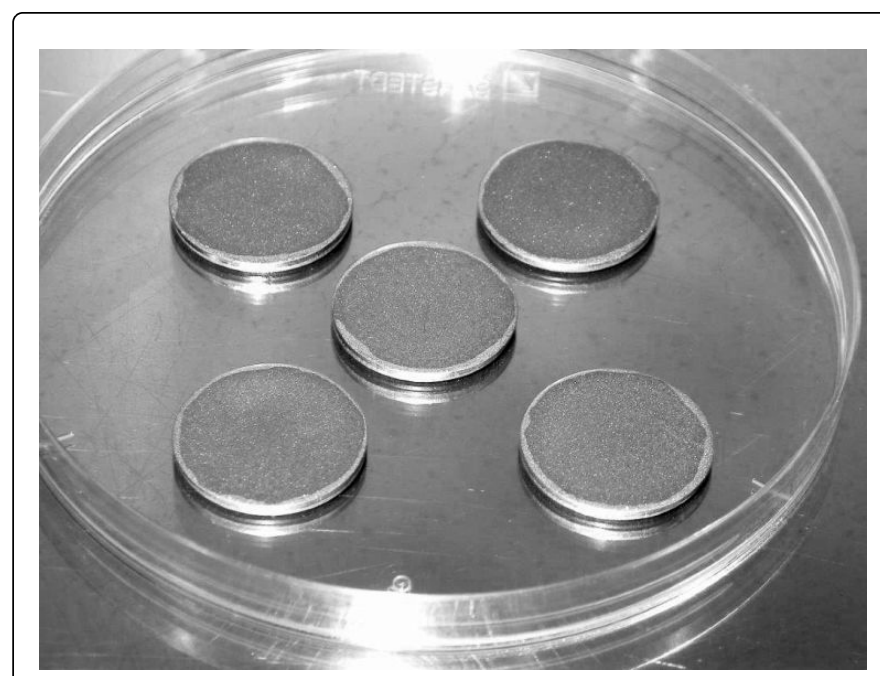

Figure 1: Virus test suspension dried onto test coupons.

Immediately after completion of ozone treatment, coupons inoculated with bacteria were transferred into $30 \mathrm{~mL}$ jars with $3 \mathrm{~g}$ sterile glass beads $(2.85-3.45 \mathrm{~mm})$ and $5 \mathrm{~mL}$ SDW. The bacteria were re-suspended by heavy vortexing for $3 \times 30 \mathrm{sec}$. Serial dilutions were plated on TSA ( $S$. aureus) or MBA ( $M$. terrae) and the number of viable bacteria was determined. 
Citation: Maier I, Chu T (2016) Use of Ozone for Inactivation of Bacteria and Viruses in Cryostats. J Cytol Histol 7: 428. doi:

Page 3 of 5

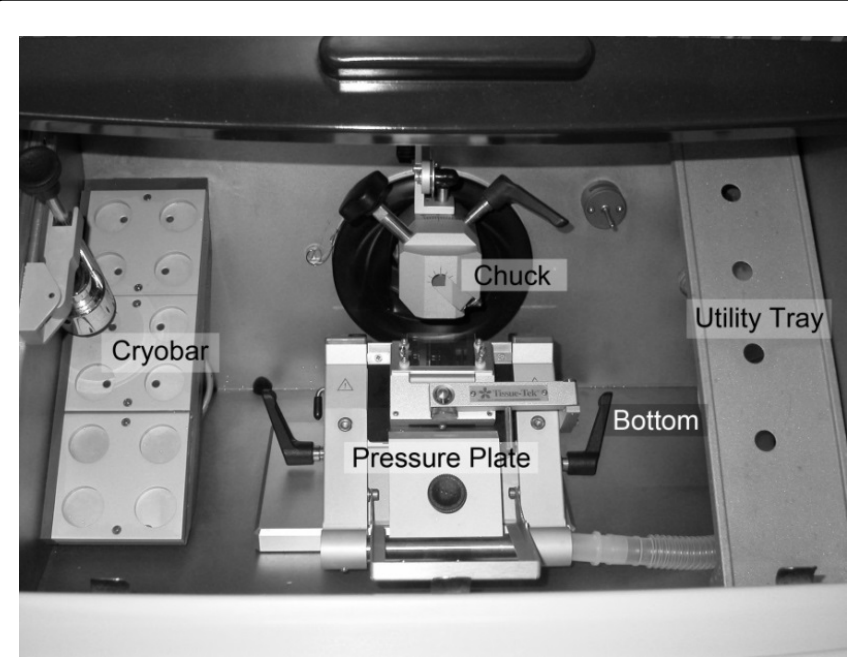

Figure 2: Test positions in the cryostat working space.

Immediately after completion of ozone treatment, coupons inoculated with bacteria were transferred into $30 \mathrm{~mL}$ jars with $3 \mathrm{~g}$ sterile glass beads $(2.85-3.45 \mathrm{~mm})$ and $5 \mathrm{~mL}$ SDW. The bacteria were re-suspended by heavy vortexing for 3 x $30 \mathrm{sec}$. Serial dilutions were plated on TSA ( $S$. aureus) or MBA ( $M$. terrae) and the number of viable bacteria was determined.

For recovery of virus particles after treatment, the coupons were immediately transferred into jars containing $0.5 \mathrm{~g}$ glass beads $(0.25-0.5$ $\mathrm{mm}$ ) and $1 \mathrm{~mL}$ virus test medium. The jars were vortexed for one minute to recover the virus particles. A defined volume of the eluate and dilutions thereof were inoculated on cultures of receptive target cells. After 17-19 days, the cell cultures were checked for cytopathic effects and the $50 \%$ tissue culture infective dose (TCID50/ml) was calculated using the Spearman-Kärber method [15]. Reduction factors were calculated from the initial and recovered viable bacterial numbers and virus titers.

\section{Results and Discussion}

The results of inactivation tests with ozone are presented in Table 1. Significant reductions in viable cell and virus numbers have been demonstrated in all ozone treatment protocols and positions tested. Despite measurements of a more or less uniform ozone steady state concentration throughout the cryostat chamber, significant differences in disinfection efficacy between test positions have been observed and require further investigation about the effect of the combination of ozone, UV, temperature and time.

\begin{tabular}{|c|c|c|c|c|}
\hline Test Strain & $\begin{array}{l}\text { Temperature } \\
\left({ }^{\circ} \mathrm{C}\right)\end{array}$ & Ozone Exposure (min) & $\begin{array}{l}\text { Test } \\
\text { Position }\end{array}$ & $\begin{array}{l}\text { Mean Reduction } \\
\text { Factor }(\log 10)\end{array}$ \\
\hline S. aureus & -20 & 30 & Pressure Plate & 4.5 \\
\hline S. aureus & -20 & 30 & Cryobar & $\geq 5.8$ \\
\hline S. aureus & -20 & 30 & Bottom & 4.1 \\
\hline S. aureus & -20 & 30 & Utility Tray & 5.5 \\
\hline S. aureus & -20 & 60 & Pressure Plate & $\geq 5.4$ \\
\hline S. aureus & -20 & 60 & Cryobar & $\geq 5.5$ \\
\hline S. aureus & -20 & 60 & Bottom & $\geq 5.4$ \\
\hline S. aureus & -20 & 60 & Utility Tray & $\geq 5.8$ \\
\hline M. terrae & -20 & 30 & Pressure Plate & 1.2 \\
\hline M. terrae & -20 & 30 & Cryobar & 2.1 \\
\hline M. terrae & -20 & 30 & Bottom & 1.0 \\
\hline M. terrae & -20 & 30 & Utility Tray & 1.9 \\
\hline M. terrae & -20 & 60 & Pressure Plate & 3.5 \\
\hline M. terrae & -20 & 60 & Cryobar & 4.0 \\
\hline M. terrae & -20 & 60 & Bottom & 2.2 \\
\hline M. terrae & -20 & 60 & Utility Tray & 4.1 \\
\hline M. terrae & +30 & 120 & Pressure Plate & $>5.3$ \\
\hline M. terrae & +30 & 120 & Cryobar & $>5.3$ \\
\hline M. terrae & +30 & 120 & Bottom & $>5.3$ \\
\hline
\end{tabular}




\begin{tabular}{|l|l|l|l|l|}
\hline M. terrae & +30 & 120 & Utility Tray & $>5.3$ \\
\hline Polyoma virus & -20 & 30 & Pressure Plate & 1.7 \\
\hline Polyoma virus & -20 & 60 & Pressure Plate & 3.8 \\
\hline Polyoma virus & -20 & 120 & Pressure Plate & 4.0 \\
\hline Polyoma virus & -20 & 120 & Bottom & 1.3 \\
\hline Polyoma virus & +30 & 120 & Pressure Plate & $\geq 5.0$ \\
\hline Polyoma virus & +30 & 120 & Bottom & 3.1 \\
\hline Polyoma virus & +30 & 120 & Chuck & $\geq 5.3$ \\
\hline
\end{tabular}

Table 1: Results of different ozone treatment regimes on reduction in microbial numbers.

Based upon the provisions of the German DGHM guideline [9] and the European norm EN 13697 [10], bactericidal efficacy for a disinfectant is shown by demonstrating a reduction in cell counts by at least $5 \log 10$ units. The present investigation confirms bactericidal efficacy of the $60 \mathrm{~min}$ ozone treatment at $-20^{\circ} \mathrm{C}$ for $S$. aureus in all test positions. In the $30 \mathrm{~min}$ period at $-20^{\circ} \mathrm{C}$, a disinfection rate of $5 \log 10$ units was achieved in some, but not all test positions. $M$. terrae required a $120 \mathrm{~min}$ treatment at $+30^{\circ} \mathrm{C}$ for a reduction rate of at least 5 $\log 10$ units.

Based upon the provisions of the German Association for the Control of Virus Diseases and the Robert Koch Institute [11], virucidal efficacy for a virucidal agent is shown by demonstrating a virus titer reduction of at least $4 \log 10$ units. The present investigation does confirm virucidal efficacy of the 120 minute ozone treatment at $-20^{\circ} \mathrm{C}$ on the pressure plate and at $+30^{\circ} \mathrm{C}$ on the pressure plate and chuck positions.

Ozone has shown to be very effective against most vegetative bacteria and viruses. In general, bacterial spores, mycobacteria and non-enveloped viruses are more resistant than vegetative bacteria and lipid-enveloped viruses [3,16-19]. The spore coat in bacterial endospores is a protective barrier against ozone [20], therefore, bacterial spores are more resistant than their vegetative forms. Compared to non-enveloped viruses, enveloped forms are more sensitive to chemical disinfectants because they require an intact lipid envelope to infect host cells, and this envelope can be damaged by chemical and physical agents. Prions might be more susceptible to ozone than some bacteria [21-23].

Reliable prediction of microbial disinfection efficiency is difficult because of the wide range of pathogens that may be present. This can be resolved by employing suitable surrogate organisms in disinfection testing. In the present study, $S$. aureus, $M$. terrae and Polyoma virus have been used. $S$. aureus is a standard Gram-positive test bacterium representing vegetative bacterial forms (except mycobacteria), whereas $M$. terrae and the relatively small, non-enveloped Polyoma virus belong to the most resistant bacteria and viruses, respectively. $M$. terrae is a surrogate for the cause of tuberculosis, M. tuberculosis, in disinfectant testing. Polyoma virus is a non-enveloped standard test virus for virucidal activity with high resistance against various disinfectants $[9-11,13,14]$.

Bactericidal acitivity against $S$. aureus and $M$. terrae, together with virucidal activity against Polyoma virus thus allow the conclusion that the $+30^{\circ} \mathrm{C} / 120$ min ozone disinfection routine in the present study achieved intermediate-level to high-level disinfection according to the $\mathrm{CDC}$ definition [24] in the pressure plate and chuck test positions. At $-20^{\circ} \mathrm{C}$, low-level disinfection is achieved in all test positions by ozone treatment for 60 minutes. However, a $5 \log 10$ reduction was achieved with $S$. aureus within $60 \mathrm{~min}$ at $-20^{\circ} \mathrm{C}$.

\section{References}

1. Roy D, Wong PKY, Engelbrecht RS, Chian ESK (1981) Mechanism of enteroviral inactivation by ozone. Appl Environ Microbiol 41: 718-723.

2. Victorin K (1992) Review of the genotoxicity of ozone. Mutat Res 277: 221-238.

3. USEPA (1999) Alternative disinfectants and oxidants guidance manual. US Environmental Protection Agency, Office of Water, Washington, D.C.

4. Thanomsub B, Anupunpisit V, Chanphetch S, Watcharachaipong T, Poonkhum R, et al. (2002) Effects of ozone treatment on cell growth and ultrastructural changes in bacteria. J Gen Appl Microbiol 48: 193-199.

5. Meunier L, Canonica S, von Gunten U (2006) Implications of sequential use of UV and ozone for drinking water quality. Water Res 40: 1864-1876.

6. Ramseier MK, von Gunten U, Freihofer P, Hammes F (2011) Kinetics of membrane damage to high (HNA) and low (LNA) nucleic acid bacterial clusters in drinking water by ozone, chlorine, chlorine dioxide, monochloramine, ferrate(VI), and permanganate. Water Res 45: 1490-1500.

7. Nicholas R, Dunton P, Tatham A, Fielding L (2013) The effect of ozone and open air factor on surface-attached and biofilm environmental Listeria monocytogenes. J Appl Microbiol 115: 555-564.

8. Emerson MA, Sproul OJ, Buck CE (1982) Ozone inactivation of cellassociated viruses. Appl Environ Microbiol 43: 603-608.

9. Gebel J, Werner H-P, Kirsch-Altena A, Bansemir K (2001) Standardmethoden der DGHM zur Prüfung chemischer Desinfektionsverfahren. Evaluation of bactericidal and fungicidal activity on non-porous surfaces]. mhp Verlag, Wiesbaden, Germany p: 40.

10. European norm EN 13697 (2002-01) Chemical disinfectants and antiseptics - Quantitative non-porous surface test for the evaluation of bactericidal and/or fungicidal activity of chemical disinfectants used in food, industrial, domestic and institutional areas - Test method and requirements without mechanical action (phase 2/step 2).

11. DVV, RKI (2009) Guideline of "Deutsche Vereinigung zur Bekämpfung der Viruskrankheiten e.V. (DVV; German Association for the Control of Virus Diseases) and Robert Koch Institute (RKI; German Federal Health Authority) for testing the virucidal efficacy of chemical disinfectants in the human medical area. Hygiene \& Medizin 34: 293-299.

12. Zoschke K, Bornick H, Worch E (2014) Vacuum-UV radiation at $185 \mathrm{~nm}$ in water treatment - a review. Water Res 52: 131-145. 
Citation: Maier I, Chu T (2016) Use of Ozone for Inactivation of Bacteria and Viruses in Cryostats. J Cytol Histol 7: 428. doi: 10.4172/2157-7099.1000428

Page 5 of 5

13. van Klingeren B, Pullen W (1987) Comparative testing of disinfectants against Mycobacterium tuberculosis and Mycobacterium terrae in a quantitative suspension test. J Hosp Infect 10: 292-298.

14. Griffiths PA, Babb JR, Fraise AP (1998) Mycobacterium terrae: A potential surrogate for Mycobacterium tuberculosis in a standard disinfectant test. J Hosp Infect 38: 183-192.

15. Hierholzer JC, Killington RA (1996) Virus isolation and quantitation. In: Mahy BWJ, Kangro HO (eds.) Virology methods manual. Academic Press, London.

16. Sobsey MD (1989) Inactivation of health-related microorganisms in water by disinfection processes. Wat Sci Tech 21: 179-195.

17. Russell AD (2003) Similarities and differences in the responses of microorganisms to biocides. J Antimicrob Chemother 52: 750-763.

18. Sharma M, Hudson JB (2008) Ozone gas is an effective and practical antibacterial agent. Am J Infect Control 36: 559-563.

19. Zoutman D, Shannon M, Mandel A (2011) Effectiveness of a novel ozone-based system for the rapid high-level disinfection of health care spaces and surfaces. Am J Infect Control 39: 873-879.
20. Foegeding PM (1985) Ozone inactivation of Bacillus and Clostridium spore populations and the importance of the spore coat to resistance. Food Microbiology 2: 123-134.

21. Ding N, Neumann NF, Price LM, Braithwaite SL, Balachandran A, et al. (2012) Inactivation of template-directed misfolding of infectious prion protein by ozone. Appl Environ Microbiol 78: 613-620.

22. Ding N, Neumann NF, Price LM, Braithwaite SL, Balachandran A, et al. (2013) Kinetics of ozone inactivation of infectious prion protein. Appl Environ Microbiol 79: 2721-2730.

23. Ding N, Neumann NF, Price LM, Braithwaite SL, Balachandran A, et al. (2014) Ozone inactivation of infectious prions in rendering plant and municipal wastewaters. Sci Total Environ 470-471: 717-725.

24. Rutala WA, Weber DJ (2008) Guideline for disinfection and sterilization in healthcare facilities. Healthcare Infection Control Practices Advisory Commitee (HICPAC), Department of Health \& Human Services USA Centers for Disease Control and Prevention; Atlanta. 